\title{
Linguistic normation in call centres and universities - how and why?
}

\author{
ANNA KRISTINA HULTGREN
}

This article sets out to shed light on "linguistic normation" in two very different types of institutions in the globalized work order: call centres and universities. "Linguistic normation" is understood as metalinguistic practices aimed at making visible the linguistic and communicative behaviour of employees. Comparing examples from call centre customer service manuals and Danish university language policies, it is argued that despite some obvious differences, the apparent urge in both workplaces to engage in "linguistic normation" is a revealing sign of the times in which we live. It is suggested that both institutions are characterized by a set of tensions which are a hallmark of the multilingual and competitive globalized work order. In the call centre, this tension is between rationalizing and providing a personalized service; in the university, it is between being a global actor and serving the domestic market. What is interesting, however, is that both institutions apparently regard language as the locus for solving these apparent tensions. It is argued that resorting to "linguistic normation" is a red herring which fails to identify and address the underlying political, economic, organizational and pedagogic factors which are the real causes of the perceived "problems" in these respective workplaces. 